\title{
Knowledge and the curriculum: Derrida, deconstruction and 'sustainable development'
}

\author{
Christine Winter* \\ University of Sheffield, UK
}

This paper enquires into curriculum knowledge about sustainable development at advanced level in geography in English schools through a critical look at two concepts. The deconstructive perspective used is drawn from Jacques Derrida. The focus is on school knowledge and responsibility to other ways of knowing that may be neglected within assumptions concerning the fixed meanings of words, universal laws and the presumptions of scientific method. Michael Bonnett, Martin Heidegger and Iris Murdoch offer transgressive ways of knowing about sustainable development. It is suggested that these ideas might lead to alternative, more ethical and political, and ultimately more objective forms of geographical knowledge.

\section{Introduction}

How is it, in the contemporary curriculum, that we are to conceive of the objects of knowledge? Put differently, what pressures-what politics, what assumptions concerning meaning and thinking - condition and constrain our understanding of the objects of study? What ethics, what orientation to the other, is embedded in our curricular practices? These are questions that transcend and reach across all phases of education. In certain respects they also expose tensions between phases, and a careful consideration of them may help to explain some of the concerns that burden the education of young people as they move from school to university.

My intention in this paper is to broach these difficult matters by way of a narrowing of the focus in order better to consider the practicalities of curriculum in which they are either manifest or otherwise latent problems. In particular I shall draw attention to aspects of the language of curriculum materials by looking closely at two geographical concepts. The aims of the paper are twofold-the first is to enquire into the nature of curriculum

\footnotetext{
*School of Education, University of Sheffield, Department of Educational Studies, The Education Building, 388 Glossop Road, Sheffield SI0 2JA, UK. Email: c.winter@sheffield.ac.uk
} 
knowledge relating to sustainable development at post- 16 level $^{1}$ in Geography through a critical look at two concepts in a textbook chapter. The second is to explore ways in which these concepts may be developed in the future. The deconstructive perspective is drawn from Jacques Derrida and is interpreted according to what we can for present purposes refer to as four tenets: (I) that words mean more than they pass themselves off to mean; (2) that pervasive frameworks of meaning reveal some things and conceal others; (3) that the ethics and politics of geographical knowledge may be neglected in AS/A level studies; and finally (4) that transgression opens the path (in ways that I shall explain) to alternative, more ethical and more political forms of geographical knowledge.

It is particularly appropriate for several reasons, to focus on a textbook as a player in the curriculum. The book is widely used in schools and, as with other school texts, it has acquired a certain authority as the representation of official knowledge that is beyond critique. This book, and ones like it are expensive to purchase, and, for this reason may not be updated and/or replaced frequently. For the purpose of this paper, it is an authentic and practical source of the conceptual knowledge engaged with by students and teachers in contemporary classrooms and therefore forms a platform on which to construct the argument.

The concepts under consideration occur in a popular Advanced level textbook called Global challenge (McNaught \& Witherick, 200I). This publication initially attracted my interest because of the close correspondence between its content and the official examination specification (Edexcel, 2002), which seemed to leave little opportunity for anything other than assessment-driven teaching. Of course, teachers use such texts selectively, and supplement them with other curriculum materials. But a question remains about the assumption underpinning this structure and correspondence. The case of geography provides a fruitful focus of discussion about curriculum knowledge. This is so partly because of the traditional dichotomization of geographical knowledge into 'physical' geography and 'human' geography, but also because of the emergence of influential currents of thought in the new geographies in higher education. These are currents that school geography has scarcely begun to register, a failure that exacerbates those problems of transition to which I have referred.

This particular text serves as a springboard to consider some of the problems that occur more widely within the geography curriculum, and indeed, across a range of disciplines both within and beyond the school curriculum. Moreover, further relevance of the discussion that follows to a wider educational audience lies in the need to retrieve the idea of deconstruction from the misconceptions that currently surround it. I do this by demonstrating, through an example, how the poststructuralist thinking that I am drawing on opens a way to a more nuanced understanding of what is in question and ultimatelycontrary to the popular perception-to more objective forms of knowledge.

I begin by exploring briefly the institutional framework of knowledge production in school geography before describing the limitations involved in focusing on textbook concepts. The context of the study is introduced, followed by an examination of Derrida's perspective. Deconstructive questions are then asked about the two concepts used in the textbook and examination specification in order to lead to alternative ways of thinking about the environment in advanced level studies. 
Put simply, there may be three main 'knowledge production' teams at work in the emergence of school geography curriculum knowledge-the first focusing on the school curriculum (DfES, QCA, GA, RGS \& IBG, NGOs, educational consultants), the second focusing on University research (journal editors, SSRC referees, University appointment and promotion committees, journal review boards, conference organizers) and the third (playing an increasing important role) - the commercial sector (publishing companies, the media). Members of all three groups have their own interests in how geography should be understood and all the groups are subject to the contemporary pressures of performativity in their respective spheres.

Moreover, looking closely at concepts in a textbook and examination specification provides only a snapshot view of the knowledge production process involved in teaching, learning and assessment. The approach is limited in three key practical respects: first, it neither directly addresses the discussions, struggles and compromises between authors, editors and publishers that have preceded these final textual forms. Nor does it consider the Government criteria dictating the structure and content of the examination specification text that feeds into the textbook design. Second, and as mentioned earlier, associated school-produced resources and particular teaching, learning and assessment strategies actually used in schools and colleges are not directly considered, nor are those social interactions and other texts that form the everyday experience of teachers and students engaging with geographical knowledge.

The third limitation appears a little obscure, but it is important to acknowledge it nevertheless. Thinking about concepts in these texts and examining them deconstructively neglects a consideration of the interpretive power of students-how do students engage with the geographical knowledge they read about in this text? Do they passively accept the ideas, or do they critically engage in them? Having stated the caveat surrounding the approach, I'll pass now to describe the context and rationale for the task I have set myself.

\section{Context: the case of geography}

School geography in England has been going through a rough patch recently, with declining numbers taking the General Certificate in Secondary Education examination (GCSE-for students aged 16) and GCE Advanced level examination (for students aged 18-years-old and over) and poor inspection reports at Key Stage 3 (for students aged I I- to I4-years-old) (Ofsted, 2005a, b). Competition for curriculum time, the use of non-specialist teachers in lower secondary classrooms and lack of appropriate resources have been identified as sources of the problem of the subject's declining popularity (QCA, 2005). Declining status in schools and colleges inevitably has implications for the future of the subject in higher education. Unfortunately, a gap exists between higher education geography and school geography, since exciting developments in geography research and teaching in $\mathrm{HE}$ following the "cultural turn' have not been passed onto to schools and colleges (Rawling, 200I). A recent action plan backed by Government funding of $£ 2$ million has been earmarked to improve the popularity and reputation of school geography (Department for Education and Skills et al., 2006).

My own opinion is that school geography knowledge is tired and dated, and that it is constrained within traditional paradigms. These facts, together with the objectives-led 
structures of the National Curriculum in England (1999), plus the contextual factors mentioned above, have contributed towards the subject's loss of appeal for many youngsters. Geography needs re-energizing, but not in a temporary fashion through knee-jerk reactions, quick-fix gimmicks and sensationalizing publicity (See Lambert, 2006). Instead it needs an unsettling, a rethink — not in a destructive way-but in a way that allows things to unravel, for new patterns and connections to emerge.

Critics of school geography knowledge in the 1970s and 1980s formed the 'radical geography educators' who probed political assumptions underlying the geography curriculum in schools (Morgan \& Lambert, 2005). Their ideas were rapidly subsumed by the regulatory and standardizing forces of the Education Reform Act (1988) and the resulting Geography National Curriculum (199I). More recent critical thinking is couched in post modern terms, understanding the geography curriculum to be one of many texts, with no essentially fixed meaning, but open to a variety of interpretations (Morgan, 2000). However, as Morgan argues, such critiques of geographical knowledge in schools as those described above remain underdeveloped and marginal (Morgan, 2002). This paper attempts to advance critical thinking about school geographical knowledge by troubling institutionalizing influences that frame meanings of geography and by opening possibilities for new ways of thinking to emerge.

The subject needs to rebuild its status and reputation as an important contributor to the curricular experience of students. It needs to both address the political and ethical deficit that has existed for so long and to attend to areas of experience previously overlooked, in order to invite engagement and thought amongst students in classrooms. In this paper, the concepts of sustainable development (SD) and resources are unsettled and encouraged to unravel. Before turning to this, I will first introduce the idea of deconstruction according to Derrida (1973, 1974, 1978).

\section{Derrida}

Deconstruction is neither analysis nor critique. It is not a method and cannot be made into one. It takes place everywhere (Derrida, 1988). Furthermore, deconstruction is not so much something that the researcher does, as something that happens if you look carefully enough ('It deconstructs it-self; 1988, p. 4). In other words, deconstruction is impossible to pin down in any tidy definition and it takes various forms. Caputo puts it like this:

The very meaning and mission of deconstruction is to show that things-texts, institutions, traditions, societies, beliefs, and practices of whatever size and sort you need—do not have definable meanings and determinable missions, that they are always more than any mission would impose, that they exceed the boundaries they currently occupy. What is really going on in things, what is really happening, is always to come. (Caputo, 1997, p. 31)

Perhaps the most surprising and significant sentence in this quotation is the final one. A simple example of one way this occurs is the kind of double life that geographical terms have: first as apparently descriptive, second as slogans. For example, 'sustainability' is a reasonable enough word to describe certain aspects of looking after things so they last into the future, but it becomes a 'tag' that is added to everything (sustainable economy, 
forest, lifestyle, transport, NHS, cities, policing ... I recently encountered the 'sustainable thinking classrooms project'!). In a way, everything on offer appears to need the pre-fix 'sustainable' to make it acceptable - it becomes a ubiquitous symbol of political correctness. At the same time, its presence punctures credibility in its meaning.

I concentrate in the paper on exploring the many lives or happenings to come of two geographical concepts referred to in chapter 8 of the textbook Global connections (McNaught \& Witherick, 200I, pp. 205-208). The chapter heading is 'Can sustainable development be achieved?' The analysis illustrates how words mean more than they appear: 'What is really going on in things, what is really happening, is always to come .... Before doing this, my interpretation of the four tenets mentioned earlier is given below.

\section{Words mean more than they pass themselves off to mean}

Derrida opposes the assumption that language is representative of thought. He agrees with the structural linguist, de Saussure, that meaning is conveyed, not through a direct correspondence between a word and a thing, but through a system of differences that ascribes meaning through ways in which the thing in question is different from other things. 'Coal', for example, belongs to a group of words for non-renewable energy, and our use of 'coal' to denote the combustible mineral mined from the ground is possible because of its distinction from other words in the category, like gas and oil.

Derrida takes this idea further when he shows that the meanings of words are always changing - a word has a history, it twists and turns in its use-we can never fix to it a particular meaning or predict the meaning of the word we use (Derrida, 1974). He uses the neologism differance to indicate that meaning is both differential (according to its difference to other words) and deferred (the word can never produce a 'true', fixed and stable meaning) (1982). To use the word 'sustainability' again as an example-according to Derrida, the meaning of the word should be allowed to unfurl-its meanings should be allowed to reach fruition and spill over-after all, the concept is of unparalleled importance regarding the future of the planet and the release of meanings may open up the possibility of something better to come.

What does this first tenet mean, then, in the context of this paper? In the textbook, concepts are presented as having clear, accurate, authoritative and legitimate meaning until they are encouraged to deconstruct - at this point it can be demonstrated that there is more to words than meets the eye, "that they exceed the boundaries they currently occupy'. In spite of the aim of the textbook authors to pin down and fix, for example, the meaning of the terms 'sustainable development' and 'resources', it can be shown that the language, under deconstructive questioning, reveals more than it appears to reveal within the text - the meaning is always and already emerging, has been influenced by its history of meanings, is embedded within suppositions that have influenced it and is wide open to an ever-changing chain of meanings (Caputo, 1997). The textbook tries to capture, tie up and, in effect, fossilize the word and the world, denying its dynamism and its responsibility to open up to new ways of thinking and new ways of including the other that have been overlooked and forgotten. 


\section{Frameworks of meaning}

Derrida is interested in the way that Enlightenment ideas steep us in certain ways of thinking that involve understanding knowledge through universalizing concepts based on the notion that the world has a fundamental order to it that pre-exists attempts by humans to understand it. Geographers Cloke, Philo and Sadler make the point well:

... the social sciences have by and large taken on board a natural-scientific notion of order existing 'out there' in the 'real' world, and have hence embarked upon quest after quest for the 'true' order of the human world-for the 'true' way in which human agents interact with one another, with their institutions and with other processes, forces, mechanisms and so on $\ldots$ and have usually accepted the natural-scientific view that this order pre-exists any attempt by human agents to conceptualize it. (Cloke et al., 1991, p. 187)

This second tenet, frameworks of meaning, involves the imposition of supposedly naturalistic and scientific order to matters that lie outside the realm of science and is known as 'scientism'. Typically it carries with it a kind of essentialism-the fundamental order of how things really are, which is burdened by a whole metaphysics. In geography this includes the identification of, for example, the use of binary opposites like physical-human geography; economically more developed country-economically less developed country (EMDC-ELDC); renewable-non-renewable energy supplies; society-nature, urban-rural and the framing of human behaviour in models (like push-pull factors), diagrams (like population pyramids), stages (like the demographic transition), patterns (like global population migrations) and processes (like natural population change). Scientism assumes that the world can in principle be known objectively-with certainty and precision — through totalizing and definitive explanations.

The crucial point here is not to deny objectivity but to question how we can achieve it objectively through totalizing and definitive explanations. This is not to undermine the need for truth-there are standards that have to be met in geography and everywhere else. There is right and wrong. But many people are not satisfied with an ordinary concept of truth, instead, they search for what Derrida calls a 'scientificist objectivism' (1974, p. 6I), a metaphysical underwriting of knowledge, which is naturalized and considered to be the 'Essence of Reality'.

Now Derrida does not refute completely such Enlightenment ideas. Instead he wants us to question these frameworks of meaning to find out how they are naturalized and how they operate to authorize and legitimate certain ways of understanding the world. At the same time, he is concerned about the responsibility that totalizing discourses carry in the sense of revealing some aspects of knowledge at the same time as concealing others.

\section{Responsibility}

'Deconstruction is justice' (Derrida, 1992, p. 15). In the case of our geography text, deconstruction sensitizes us to something stirring, possibly amiss or missing, within the assumptions of the fixed meanings of words, universal laws, and the presumptions of scientific method. Derrida's deconstruction of the Enlightenment commitment to order does not destroy or jettison these ideas but picks them over like a rag picker, to find the 
'bits and pieces that tend to drop from sight in the prevailing view of things' (Caputo, 1997, p. 52). The rag picker uses the rags - the unwanted, overlooked remnants of cloth-picking up loose threads to create something new. This is a responsibility to the other that has been omitted, forgotten and left out-it is a more exacting objectivitybecause deconstruction is first of all an affirmation of the advent of the other.

What is 'the other' in the context of geography? On the one hand, it may be other groups of people that have been neglected in the way meaning is fixed in the text or in the way totalizing discourses categorize and organize knowledge. For example, in the textbook chapter, reference to how and why particular communities are affected by problematical environmental conditions is omitted as SD is discussed using generalized, ahistorical, apolitical language. On the other hand, the textbook chapter downplays the affective side of human experience, emphasizing instead (again in general, ahistorical, apolitical and anodyne terms), notions like 'affluence' and 'poverty'. Other ways of knowing, such as the compassionate, spiritual, ethical and political may be overlooked in the way knowledge is configured. I now move to the fourth tenet, transgression, which relates the idea of responsibility to the earlier discussion about 'what is really happening, is always to come'.

\section{Transgression}

Responsibility in the Derridean sense alludes then to other, more transgressive ways of knowing that escape modernist categories and tidy conceptual schemes and arbitrarily exclude affect, thereby allowing us to look outside ourselves towards a moral, affective and creative side of thinking. Through the opening of other diverse and sensuous approaches to knowledge- for example, through intuition and inspiration, through art and through literature, we look to introduce a more responsible and more truthful knowledge into geography education. The following discussion focuses on the otherness of objects of geographical knowledge as a means of affirming alternative ways of knowing in the advanced level geography curriculum.

How we are in the world in the fullest sense-how we live the world, feel the world, think the world and write the world should form the essence of geographical thought, policy and practice in the school and college curriculum. It is important to resist our tendencies to think of the world in naturalized terms. We need to see that what we mean by the world - not in some fancy postmodern phrasing but in our ordinary thinking-is not some substrate of trade balance or gross national product-but the world in which there are trees and rivers and shops and cars. These things have come to light in this way because of human purposes. I now look closely at two concepts that appear in the textbook to try to demonstrate the ideas described above.

\section{Sustainable development}

The first concept is 'sustainable development', a term that, as it is commonly understood in the geography education community, can be tracked back to the Brundtland Report of 1987 (WCED). Under the heading 'What is sustainability?' the first sentence of page 205 is: 'Sustainability describes the relatively recent and hazardous situation that faces the 
world'. But does it? If recent world environmental problems can be described as 'sustainability', then what hope is there for the future? This statement gives the chapter a confusing start, which is confounded further by the rhetorical power of the term itself. In the textbook, the term SD is presented as unproblematical-but on deconstruction, it reveals more than it appears to reveal in the text.

Let us allow it to deconstruct. 'Sustainable development' is referred to by Stables as a 'paradoxical compound policy slogan'-a term to which no one, it seems, can object (1996, p. 162). Second, it relates to attending to the needs of future generations, but, how can we presume to know with any certainty what the needs of future generations may be? (Meadowcroft, 1999). Third, there is the problem of how continued economic growth can ever solve global poverty and prevent environmental degradation when even current levels of resource use are unsustainable (Reid, 1995).

In this sense, the term 'sustainable development' may be regarded as an oxymoron. Fourth, an assumption underpinning the Brundtland Report is the belief that a western model of economic growth, one that tends to overlook the politics of the inequitable relationships between the North and the South within the global economy, is inevitable and essential (Orr, 1992).

Finally, the Brundtland conceptualization of SD assumes a distinction between humans and the environment in which humans are privileged over non-humans. Such a hierarchical dichotomy is currently being challenged on two fronts, both of which address questions concerning who or what has ethical standing and who or what are the proper objects of ethical concern. On the one hand, relational thinking (Haraway, 199I; Latour, 1993; Whatmore, 2002) unsettles distinctions between humans and non-humans, especially in the light of the blurring of categories that is demonstrated by such developments as genetically modified mice, biologically engineered body parts and cloned animals (Valentine, 2004).

This kind of challenge to the assumption of the dominance of humans over non-human is referred to by Castree (2003) as a post-environmental ethics. Such an ethics is founded not on a 'material essentialism' that assumes a categorical human/non-human distinction, but on an emergent hybridity contingent upon human/non-human interaction. Is a human with a transplanted pig's heart truly 'human'? On whose authority do humans take a pig's heart for human transplant purposes? The result of relational thinking is that we cannot make assumptions that the group we call 'human' is, in fact human, or that its members have the right to make life or death decisions on behalf of other categories of being.

On the other hand, an alternative understanding of the relationship between humans and non-humans is offered by Bonnett. He emphasizes the non-instrumental nature of this relationship, suggesting that it is characterized instead by an aspiration of:

... attunement; a sensing of harmony and discord in terms of a more intuitive acquaintanceship with nature/the environment and our responsibilities towards it. And its central qualities will be receptiveness and a genuine responsiveness which is open to, and engaged with, the many-sidedness of things themselves in the way that, for example, great art and literature can be. (Bonnett, 1999, p. 321)

He argues that humans and non-humans can never be ecologically and morally equal because of the special place of humans as the only beings that can be responsible, or 
experience responsibility towards the environment (1997). Both lines of argument alluded to here attempt to show that the relationship between humans and non-humans may not be as unproblematical as the dominant conceptualization of SD assumes.

On the surface, then, SD trades off a feel-good factor, conjuring up warm and cosy feelings of decency, fairness and planetary care, since the idea that resources can be virtuously conserved (sustained) at the same time as being gleefully consumed (developed), is in one sense reassuring, but, at the same time, conceals some fundamental problems. The oxymoronic nature of SD is typical of a political 'spin' of the 'have it both ways' approach that encompasses everything and suspends critical thought until tomorrow. There is, however, more to the term than it seems. Sustainability is not compatible with economic development that is associated with capitalism (Bonnett, 2003) and the prevailing model of western industrial development underpinning the Brundtland notion of 'development' actually represents a source of current environmental problems rather than a solution to them. Bonnett reveals his suspicion in the rhetorical form of the term SD when he writes:

\footnotetext{
... there is a seductiveness in seeming to marry two highly desired goals of sustainability and development, apparently bringing them into convenient harmony. However, with the growth of its appeal and influence there has arisen a suspicion that 'sustainable development' might involve a certain semantic sleight of hand that veils an undergrowth of ambiguities and tensions which are in danger of vitiating the notion and consequently any environmental policy that is based upon it. (Bonnett, 2003, p. 676)
}

The term SD is not as straightforward as it appears. Let us now turn our attention to resources - the second concept-which is commonly understood in relation to sustainable development, and on the first page of the chapter under study (p. 205) it is referred to ten times.

\section{Resources}

The word 'resource' derives from the Latin word resurgere meaning to rise or surge again (resurrection [restore to life], revive, resurgence). This meaning may be traced via the Old French word resourdre-to relieve or rise again. The contemporary OED definition of 'resource' is 'stock or supply of materials or assets'. The etymology of the word illustrates its changing meaning and provides a clue to understanding how it has been taken up in the age of technology. In The question concerning technology, Heidegger refers to such assembling and ordering of things ('a calling forth, a challenging claim') in the modern world as 'Enframing' (1977, p. 19). Thinking about global resources in terms of stock or supply orders and reveals the world through a technical rationality that amplifies certain ways of being at the same time as concealing others. Calculation of resources surreptitiously orientates us to think of the world as reducible to the technical, that it may be understood according to what might be thought of as an exact science.

Understanding global resources as raw material and goods, imports and exports, production and consumption distances us from thinking otherwise-reducing the world to measurable phenomena, to materials or assets, or, as Heidegger again puts this, 'standing reserve' (Heidegger, 1977) — to reserves, that is, that are waiting to be used up: 
It remains true, nonetheless, that man [sic] in the technological age is, in a particularly striking way, challenged forth into revealing. That revealing concerns nature, above all, as the chief storehouse of the standing energy reserve. Accordingly, man's ordering attitude and behavior display themselves first in the rise of physics as an exact science. Modern science's way of representing pursues and entraps nature as a calculable coherence of forces. (p. 2l)

... the rule of Enframing, which demands that nature be orderable as standing reserve. ... that nature reports itself in some way or other that is identifiable through calculation and that it remains orderable as a system of information. (p. 23)

But worse than this, traditional world resource production and consumption statistics and flows make us think of ourselves as 'lords of the earth' (p. 27) with the power to acquire and consume its resources at will. Although Heidegger was writing about technology and Enframing in a very general sense, as a way of thinking, it is particularly appropriate to this discussion of resources in the context of the geography curriculum.

This technological way of thinking hides many aspects of the way humans live in the world - the spiritual, the political, the emotional, the ethical-and blocks the poiesisthe bringing forth or revealing of alternative ways of thinking and being in the world. Heidegger writes: 'The botanist's plants are not the flowers of the hedgerow; the "source" that the geographer establishes for a river is not the "springhead in the dale" (1962, p. 100). So too, seeing the earth in terms of physical resources obscures the sense of place that is involved in 'dwelling' (wohnen) - that is, the relationship between humans and space - that is geography (197I). The recourse to the poetic here is not a mere turn to the literary, to the conventionally 'poetic', but an acknowledgement of the way that language speaks, the effects of unstable meanings that reveal 'sur-prises' and that overtake the author. Rather than fixing the word 'resources' in a system of calculative ordering, allowing the word to deconstruct recognizes it's poiesis - that is, the opportunities presented by the unraveling of meaning beyond an understanding of 'nature ... as the chief store house of the standing energy reserve' (1977, p. 21).

Heidegger's way of getting closer to this is to distinguish between thinking vital to our technological relationship to the world and the place that is characteristic of our dwelling. In language that is overtly defiant of more scientific modes of thought, he attempts to acknowledge the different dimensions that constitute this dwelling-our dependence upon the earth for our sustenance, our being subject to the changing seasons and being conditioned by time itself, our orientation by certain values, by ideals and aspirations, and the inevitability of our death. He pictures us as living in the intersection of these forces, in the fourfold of earth, sky, gods and mortals: 'To preserve the fourfold, to save the earth, to receive the sky, to await the divinities, to escort mortals - this fourfold preserving is the simple nature, the presencing, of dwelling' (Heidegger, I97I, PP. I58-159). He describes how 'mortals dwell in the way they preserve the fourfold in its essential being':

Mortals dwell in that they save the earth. ... Saving does not only snatch something from a danger. To save really means to set something free into its own presencing. To save the earth is more than to exploit it or even wear it out. Saving the earth does not master the earth and does not subjugate it, which is merely one step from spoliation. (Heidegger, 1971, p. 150)

This is a robust attempt to face up to and to see beyond the enframing tendencies of technology with regard to a resource-based conceptualization of the environment. It is not 
that there is something essentially wrong with a technological view in writing about the earth's resources. The language of technology (its ways of reasoning and operation) is one way in which the world comes to light, but it has a characteristic tendency-Heidegger claims that it is unique in this respect-to dominate or crowd out other ways of thinking, and hence other ways in which the world can be revealed. A rigour is required in allowing the world to come to light, and a humility is required in recognizing our partiality in the act of bringing it forth-it is not possible that everything can simultaneously come to light. The emphasis here is on truth as aletheia (that is, on truth as that which is taken out of the River of Forgetfulness) as opposed to truth as adequatio (that is, as correspondence or representation). Our partiality forms a kind of responsibility towards the environment.

\section{Transgressing the concepts of SD and resources}

The next task is to prepare the way for the incoming of a more just, more ethical and more objective form of geographical knowledge arising out of the preceding discussion of the concepts of 'sustainable development' and 'resource'. One proposal is the replacement of the notion of sustainable development as it is currently understood by Bonnett's idea of 'sustainability as a frame of mind', a conceptualization that avoids technical rationality and instrumentalism, developing in us a 'right relationship with nature' (2003, p. 683). This orientation values a sense of harmony with nature, recognizes human responsibility for nature, encourages direct and indirect experience of involvement with nature and advocates an engagement with nature as intimate, intuitive and sensuous. Sustainability as a frame of mind calls for a disposition towards the environment that encompasses affective, moral, aesthetic and imaginative responses.

Bonnett's approach is neither goal-oriented nor objectives-led; it is not engaged in through specifications or key questions-it cannot be imposed on students but has to be allowed to arise and to follow its own path. Sustainability as a frame of mind also has a political dimension in Bonnett's view, and this cannot be realized where study is confined to the symptoms of environmental degradation and not the causes. Enquiry into environmental problems must then involve critical attention to the ethics of political and economic motives underpinning decisions, together with consideration of the parts played by those with vested interests. He stresses the need to instill into young children not only a human ethic but an environmental ethic.

Iris Murdoch (1970) says something similar, which may be related to sustainable development and resources, when she writes about the ethics of knowing and 'unselfing'. She argues for moral improvement or making ourselves better by breaking away from reductive conceptualizations of the world around us that are evident in generalizations about the earth's resources, in this case, in the form of global balance sheets of resource statistics and calculations, debit and credit. She believes that the experience of beauty and nature are the means of improving our ethics as humans, and effecting moral change, saying that these are the most important and accessible starting points for moral change as they stop us from thinking about ourselves, they direct our gaze from introspection and personal acquisitiveness. Art, according to Murdoch gives us the opportunity to forget ourselves and take pleasure in the natural, the mystical and the spiritual. 
Bonnett's and Murdoch's sense of knowing in relation to geography leads us to search out what Caputo calls the ragpicker's rags - the bits and pieces of being human that were overlooked and left out of the presumptions of modern scientific method that dominate the subject.

\section{Conclusion}

In its attempt to address broad concerns about knowledge and the curriculum, this paper began by identifying two aims. I have tried to show how a deconstructive reading of two concepts found in a geography advanced level specification and textbook uncovers presuppositions associated with knowledge about SD and resources that have been irresponsibly forgotten and left out. These omissions indicated openings to alternative ways of understanding the concepts that, it may be argued, encourage us to think differently in the future - in ways that are more ethical and ultimately, more true. There are, of course, risks associated with exploring discourses that engender affective and moral dimensions of thought - they can be used in sensationalized and sentimentalized ways when students are not entirely motivated and committed to learning. The deployment of such strategies should be resisted for their emotionalism and their lack of serious engagement with the politics and ethics of knowledge as discussed in this paper.

The approach looks closely at two concepts in a textbook chapter. The textbook ideas I address occur precisely there, in the textbook, and this conditions the way they are received by the students and the teachers. Norris's words about the way that the medium of the book itself epitomizes a certain conception of knowledge are apt: 'And this mimetic regime finds its ultimate authority in the book, in that idea of a self-enclosed totality of meaning where the logos can preside and impose firm limits on the play of textual inscription' (1987, p. 47). These geographical ideas automatically have a certain authority, they are positioned in a specialized discourse, they solicit an attitude of acquiescence on the part of students and teachers in their requirement to that discourse's terms.

Looking closely at these two concepts may serve a purpose in demonstrating the scope of an approach that may be developed further in the context of other geographical knowledge in schools. The case rests on the belief that Derrida's deconstructive perspective offers the opportunity to rethink and re-energize the subject and to reverse the trend of its declining popularity. Geography has an important contribution to make to the school curriculum. It may be time to step outside constraining modernist configurations that have restricted and concealed meaning in the subject by drawing on Derrida for inspiration to open up and invigorate geographical study in schools and colleges.

At a more general level, the paper also attempts to show how deconstructive thinking can pave the way to what Derrida calls the dehiscence of meaning-that is, the spilling forth or release, as from a seedpod, of ideas that uncover the otherness of objects of knowledge, revealing, for example, new aspects of the nature of our thinking and hence, of what is to count as reality, and fostering a more moral and selfless disposition towards and in the world. Bonnett, Derrida, Heidegger and Murdoch make us think about the importance of our language to our thinking and being and about the possibility of our being released from its more constricting forms: they are all sensitive to the fact that 
language of certain kinds can stand in the way, sometimes channeling us into a thinking that is harmful. Engagement with the possibilities of other ways of thinking may serve as an alternative to the traditional technical-rational systems that have, for so long, become naturalized both within geography and within the curriculum as a whole.

\section{Notes}

I. Post-16 level or Advanced Subsidiary/Advanced (AS/A level) General Certificate of Education (GCE) study occurs in school sixth forms or colleges in England

\section{Notes on contributor}

Christine Winter researches in curriculum, curriculum policy and change, geography, geography education, globalization and post structural thinking. She is interested in exploring how a Derridean deconstructive perspective can be used in relation to school curriculum policies. She directs the MA education policy and practice course, teaches on the Sheffield Ed.D. and coordinates an educational research module on the Caribbean programme.

\section{References}

Bonnett, M. (1997) Environmental education and beyond, Journal of Philosophy of Education, 3I (2), 249-266.

Bonnett, M. (1999) Education for sustainable development: a coherent philosophy for environmental education?, Cambridge Journal of Education, 29(3), 313-324.

Bonnett, M. (2003) Journal of Philosophy of Education, 37(4), 55I-730.

Caputo, J. (1997) Deconstruction in a nutshell: a conversation with Jacques Derrida (New York, Fordham University Press).

Castree, N. (2003) A post environmental ethics?, Ethics, Place and Environment, 6(I), 3-12.

Cloke, P., Philo, C. \& Sadler, D. (1991) Approaching human geography: an introduction to theoretical debates (London, Paul Chapman).

Department for Education and Skills, Geographical Association, Royal Geographical Society \& Institute of British Geographers (2006) Geography in action 2006-2008.

Derrida, J. (1973) Speech and phenomena and other essays on Husserl's theory of signs (Evanston, IL, Northwestern University Press).

Derrida, J. (1974) Of grammatology (Baltimore, Johns Hopkins University Press).

Derrida, J. (1978) Writing and difference (London, Routledge Kegan Paul).

Derrida, J. (1982) Margins of philosophy (Chicago, University of Chicago Press).

Derrida, J. (1988) Letter to a Japanese friend, in: D. Wood \& R. Bernasconi (Eds) Derrida and différence (Evanston, IL, Northwestern University Press).

Derrida, J. (1992) Force of law: the 'mystical foundation of authority', in: D. Cornell, M. Rosenfeld \& D. Gray Carlson (Eds) Deconstruction and the possibility of justice (London, Routledge).

Edexcel GCE Specification (2002) Advanced subsidiary GCE geography B (82/5) and advanced GCE geography B (9215) (Mansfield Notts, Edexcel).

Haraway, D. (1991) Simmians, cyborgs and women (New York, Routledge).

Heidegger, M. (1962) Being and time (Oxford, Blackwell).

Heidegger, M. (197I) Building dwelling thinking, in: M. Heidegger, Poetry, language, thought (New York, Harper \& Row).

Heidegger, M. (1977) The question concerning technology and other essays (New York, Harper \& Row). 


\section{C. Winter}

Lambert, D. (2006) The surprising and amazing power of geography: the 2006-2008 Action Plan, Teaching Geography, 3I (2), 49-50.

Latour, B. (1993) We have never been modern (Cambridge, Harvard University Press).

McNaught, A. \& Witherick, M. (200I) Global challenge A2 level geography for Edexcel B (Harlow, Longman).

Morgan, J. (2000) The future of the geography curriculum, in: D. Lambert \& D. Balderstone (Eds) Learning to teach geography in the secondary school (London, RoutledgeFalmer).

Morgan, J. (2002) 'Teaching geography for a better world'? The postmodern challenge and geography education, International Research in Geographical and Environmental Education, I I(I), I5-29.

Morgan, J. \& Lambert, D. (2005) Teaching school subjects I I-I9 geography (London, Routledge).

Meadowcroft, J. (1999) Planning sustainability (London, Routledge).

Murdoch, I. (1970) The sovereignty of good over other concepts (London, Routledge).

Norris, C. (1987) Derrida (London, Fontana).

Ofsted (2005a) The annual report of Her Majesty's Chief Inspector of Schools, Ofsted subject reports 2003/4 geography in secondary schools, HMI 233I, February. Available online at: www.ofsted.gov.uk/publications/ annualreport0304/subject_reports/secondary/geography (accessed I 2 September 2005).

Ofsted (2005b) The annual report of Her Majesty's Chief Inspector of Schools, 2004/5 geography in secondary schools. Available online at: www.ofsted.gov.uk/publications/annualreport0405/4.2.6.html (accessed 13 March 2006).

Orr, D. W. (1992) Ecological literacy: education and the transition to a postmodern world (Albany, State University of New York Press).

QCA (2005) Geography 2004/5 annual report on curriculum and assessment (QCA/05/2168) (London, QCA).

Rawling, E. M. (200I) Changing the subject (Sheffield, The Geographical Association).

Reid, D. (1995) Sustainable development: an introductory guide (London, Earthscan).

Stables, A. (1996) Paradox in compound educational policy slogans: evaluating equal opportunities in subject choice, British Journal of Educational Studies, 44(2), I59-167.

Valentine, G. (2004) Geography and ethics: questions of considerability and activism in environmental ethics, Progress in Human Geography, 28(2), 258-263.

Whatmore, S. (2002) Hybrid geographies (London, Sage).

World Commission on Environmental Development (WCED) (1987) Our common future (Oxford, Blackwell). 